\title{
COMPETING FOR INHERITANCE The Contestation between Islam, Adat and Modernity in Inheritance Distribution in Indonesia
}

\author{
Abdul Basith Junaidy \\ UIN Sunan Ampel, Surabaya - Indonesia
}

\begin{abstract}
Book Titles: M. Amin Suma, Keadilan Hukum Waris Islam dalam Pendekatan Teks dan Konteks (Jakarta: Rajagrafindo Persada, 2013), xii + 146; Yaswirman, Hukum Keluarga: Karakteristik dan Prospek Doktrin Islam dan Adat dalam Masyarakat Matrilineal Minangkabau (Jakarta: Rajagrafindo Persada, 2013), xi +342.
\end{abstract}

There are two books under review. All are written in Indonesian language. They all discuss Islamic inheritance law in one way or another. The first book is written by Professor Muhammad Amin Suma, the long serving dean of Islamic law faculty at the Islamic state university Syarif Hidayatullah Jakarta. His booklet entitled Islamic Inheritance law; from textual and contextual approach, consisting of 146 pages divided into 13 chapters. In his introduction, he stated that this booklet is written as a result of several questions raised by Muslims on the issues surrounding Islamic inheritance law, especially the different portion between men and women. As well understood in Islamic inheritance law, female heirs potentially receive only a half of male heirs in certain cases. As a conservative, he cannot hide his misgiving the increasing number of Muslims who question this different 
inheritance portion. Thus, his objective in writing the booklet is to provide apology to defend Islamic inheritance law, which is highly based on eternal textual foundation in the Holy Qur'an.

After giving introductory to Islamic inheritance law, its theological foundation, its history and application Professor Amin Suma's main argument is laid down in chapter 8 of this booklet in which he listed 25 (twenty-five) arguments of the validity of bigger portion of Muslim men in inheritance. As the title of booklet suggest, his argument is not only based textual references but also contextual basis as well. As to textual references, he ague, and rightly so, that Islamic inheritance law is among a few law in Islam which is directly derived from the holy Qur'an. This simply means the law is strongly anchored in Islam and therefore mandatory for Muslim to apply. The qu'ran injunction, which is categorized as absolute (mubkamat) and certain (qat'iyyat) as the verses on inheritance, must be accepted as given and applied as prescribed without alteration. Professor Amin Suma elucidates that the arguments of the proponents of equal portion is merely based on sociological and empiric-pragmatic arguments. According to him, the study of Islamic law, and Islamic inheritance law in particular, must depart from these divine textual foundation before embarking to contextual interpretation. A contextual thought cannot be achieved by ignoring textual references.

In addition, this inheritance law is only a part of the whole package of Islamic family law which gives men more responsibility than women, for instance, the role of husband in family as the head of family and marriage guardian of the women in the family. In addition, the bigger portion for men is not absolute. In some cases, especially when involving brothers and sisters or father and mothers, the portion is identical. Thus, larger portion of inheritance for men is legally justified.

To further strengthen his view, the author asserts that Islamic inheritance law radically improved he inheritance rights of women. In pre Islamic Arab, women arguably did not get any right to inherit. This similar fate also happens to women in some adat communities in Indonesia (p. 56-57). In term of sociological approach, which is actually the argument of proponents of equal portion of Islamic inheritance, the author argued that although in some cases play equal roles, the majority of women remains subordinates of men. Sociologically speaking, Professor Amin Suma asserts that men will 
always aware of his responsibility to provide maintenance their family. In contrast, women have no such preoccupations. Rather, they will enjoy maintenance and dowry from their husbands. Further, the professor argues that although women now work to generate income, men still dominate working forces in all sectors. Unfortunately, though, he does not provide any statistical data for this claim.

Having outlined his disagreement with the idea of revising the portion of inheritance, the author suggest those who still wish to divide inheritance not based to Islamic law to initially divide the property based on Islamic inheritance law. After all inheritors know their share of the property in this basis, they may divide it with the method they wish. This solution is not new way to formally observes Islamic inheritance law. Moreover, inheritance is a right, not an obligation. However, it substantially and gradually put aside Islamic law.

Admittedly, the issue surrounding equal (or unequal) portion between men and women in Islamic inheritance law is not new. In Indonesia, this issue become a major public discourse when in 1990s Dr. Munawir Sjadzali, a minister of Religious Affairs during Soeharto presidency and a western educated Muslim intellectual, wrote a booklet expressing his support to equal portion between men and women in Islamic inheritance law (p. 121). since then debates on the issue in many forms and venues never ceased. This booklet is arguably the most available comprehensive response from the conservatives. It does not only provide arguments from textual references (the Holy Qur'an and Prophet tradition), but also challenges sociological argument, however deficient it is, posed by the proponents of equal inheritance portion between men and women in Islamic law.

Among those who advocate the identical portion of inheritance property rely on adat law. This brings us to the second book written Professor Yaswirman, a professor of law from Andalas University, Padang. The book is entitled a published version of the doctoral dissertation by the author. The book is a 327 page long divided into 7 (seven) chapter. This book does not specifically discuss inheritance law, but discuss all aspects of adat law in Minangkabau West of Sumatra, where contestation between adat law and Islamic law is so fierce since coming of Islam until (arguably) today. As its title suggest, the book discusses characteristic and prospect adat law and Islamic law in the area of family law in Minangkabau matrilineal community. The 
aspect of inheritance law is specifically discussed in chapter $\mathrm{V}$ of the book.

The discussion about adat law in Indonesia always brings back the Dutch colonial policy in the area of law and Islam in then Netherland East Indies simply because it was the Dutch who elevated adat as law for indigenous people during their administration. Indeed, this is about the politics of law. The author accused this policy for having set aside Islamic law. The method of this enactment was represented by three theories which was perceived by Dutch legal experts as being contested by adat law and Islamic law. Van Den Berg proposed theory of Receptio in Complexu which saw Islamic law as becoming the law of Indonesian people. Their adat is Islam because there had been total acceptance of Islamic law. However, Van den Berg still acknowledged that there were exceptions in which Islamic law was not applied by Indonesian Muslims. This, in turn raised the second theory by Snouck Hurgronje and van Vollenhoven which said that Islamic law was only applied whenever adat accepted it. Thus, Islamic law only appeared in the name of adat law. In addition, there were only certain parts of the law of indigenous people which were influenced by Islamic law, notably in the area of rituals, theology and family law (including marriage and inheritance). Furthermore, Ter Haar, a student of van Vollenhoven, exclude Islamic inheritance law from adat law arguing that indigenous people used adat law in inheritance using the example of Minangkabau inheritance law. The matrilineal community of Minangkabau is simply contradictory to the concept of parental bilateral in Islamic inheritance law, in which men and women are inheritors.

Although van Vollenhoven proposed this theory as an effort to prevent the plan of Dutch authority to enact Dutch law to all Indonesian people, and he succeeded in this cause, this in turn put Islamic law in unfavorable position for a long time. The Dutch administration positioned adat law (not Islamic law) as the positive law for indigenous people and curtailed the authority of Islamic courts as a result.

Therefore, after independence, several Indonesian legal experts, suh as Hazairin and Sayuti Thalib proposed a third theory of Receptio a Contrario in an attempt to reverse the previous theory. This theory stated that adat law is applicable if it does not contradictory to Islamic law. Thus, adat law will only be acknowledged under the name of 
Islamic law. This theory, according to the author, does not easily sway the situation on the ground since the Reception theory has been adopted as the legal policy of the state. It was only in 1970 that the position of Islamic law was gradually rehabilitated with the acknowledgment of religious court as one of several judicial powers in Indonesia. The enactment of marriage law in 1974 and law of religious court law in 1989 and its amendment in 2006 further fortifies this Receptio a Contrario theory. Still, the situation in Minangkabau is not that easy to reverse. It takes a long process until today.

The author exercised inheritance law of Minangkabau using this Receptio a contrario to prove that the minangkabau community applied their adat law as long as it does not contradict to Islamic law. However, this is a never ending process in a sense that the dialog between adat and Islam continues until today with the tendency of observance of Islamic law and abandonment of adat law. Initially, the contestation between adat and Islamic law is so fierce, and once it had triggered civil war in the region (Paderi War, 1830). Shaikh Ahmad Khatib (d. 1916), a representative of Islamic law even denounced the practiced adat law of inheritance in Minangkabau which was matrilineal and based on its agrarian culture. Thus, it is contradictory to Islamic law. All property belongs to community and they are inherited by nephews, not offspring and immediate family members. Several years later, there was Marapalam consensus that attempted to reconcile adat law and Islamic law with its well-known slogan; adat basandi syarak, syarak basandi kitabullah. Syarak mangato, adat memakai (adat is founded of Islamic law, Islamic law is originated from the Holy Qur'an. Whatever Islamic law decides, adat will apply). The property in Minangkabau was then divided into two categories, Pusaka Tinggi (higher property) and Pusaka Rendah (lower property). While the higher property which acquired from farming activities in land owned by community shall remain the rights of community, the lower property, which is generated through trading or other means will be inherited among offspring and immediate family members of the deceased.

The author also provides first-hand accounts in form of court cases and interviews to prove his argument that the departure from adat law change does occur. Minangkabau community, especially those who have migrated to other region felt less obliged to observe their adat. At least, they apply adat law as formality, and substantially observe other law. The author quickly claims that since Minagkabau 
community are Muslims, this other law is predictably Islamic law. In practice, when lower property is divided, nucleus family members are prioritized as it is in Islamic inheritance law, but nephews will remain get their shares. Minangkabau community believes that dividing inheritance using Islamic law of inheritance is the most appropriate. So, after all inheritors get their shares, small portions of their shares will be bestowed to nephews on consensual basis as a symbol of honoring adat law. This is simply because Minangkabau community cannot rely anymore to higher property which is based on agrarian lifestyle to support their lives. Thus, they work to earn lower property so that the position this property becomes more significant than the higher one. This, in turn, bolstered the position of parent and at the same time undermined the role of tribal elder of Minangkabau. Therefore, the author concludes that although adat law of Minangkabau is firmly matrilineal, this does not prevents the implementation of Islamic law in Minangkabau. This adat law which has been living in the community remains applicable alongside with Islamic law. The experience in Minangkabau shows their willingness to find common ground to find harmony of the two entities which constitute identity of Minangkabau community.

Overall, this book is very rich in information. Its historical timeline is adequate except its failure to provide important accounts such as the date of Marapalam consensus, not mentioning the names of important personalities in the discussion, and the role of Shaikh Ahmad Khatib in the debate. In addition, the author seems to generalizes the dynamics of adat in Minangkabau as a result of people increasing commitment to Islamic law. in fact, Islamic law is not the only factor that contribute to this phenomenon. The role of state in politics of law, irrelevance of agrarian culture to modern people, and pragmatism also contributed to this shift. The evidence is that some departure from adat inheritance law does not resort to Islamic law. instead, the use other mechanism, such as bequest and Dutch law. however, this book is recommended for those who studies the dynamics of adat law in contemporary Indonesia from the perspective of historical politics of law. This is reasonably comparable to anthropological work by John R. Bowen in Aceh. [] 